\title{
Correlates of Entrepreneurship in Pakistan: The Regional Dimension
}

\section{Mahnoor Asif* and Anum Ellahi**}

\begin{abstract}
This study analyzes entrepreneurial ability in Pakistan through a crosssectional comparison of provinces and districts based on data from the Global Entrepreneurship Monitor for 2010-12. The aim is twofold: to (i) identify individual and country-level factors that affect nascent and potential entrepreneurs and (ii) see how regional income levels and the degree of development affect entrepreneurship (of both the opportunity and necessity varieties), eventually contributing to innovation and economic growth. We investigate the effect of total early-stage entrepreneurial activity on entrepreneurial framework conditions at the regional level and then evaluate the impact of education, age, gender and entrepreneurial ability on potential entrepreneurs, nascent entrepreneurs and baby business owners to examine the entrepreneurial startup process.
\end{abstract}

Keywords: Entrepreneurship, income, development, regional, Pakistan.

JEL classification: L26, O10.

\section{Introduction}

According to the Solow model (and many others), a country's economic growth depends on its technology and investment in innovation. This requires investing regularly in research and development (R\&D), with individuals who are willing to take on the associated risk of business ventures that may or may not succeed. Young entrepreneurs play an important role in this context because they are thought more likely to invest time and capital in business ventures that evolve around new technology.

According to the World Bank (2016, p. 225), Pakistan's ranking in terms of the capacity for starting new businesses has fallen from 114 in 2015 to 122 as of 2016. This may be due to the poor credit environment, political instability or lack of initiative. Aldrich and Martínez (2001) explain that, while anyone can start a business, not everyone can make a success of

\footnotetext{
* Teaching fellow, Lahore School of Economics.

** Teaching and research fellow, Lahore School of Economics.
} 
it. The empirical literature identifies two types of entrepreneurs: necessity and opportunity entrepreneurs. Opportunity entrepreneurs tend to be hardworking, growth-oriented and more successful with regard to survival and profitability. Opportunity entrepreneurs are ambitious and focus on innovation and creativity. ${ }^{1}$

While there is a vast body of empirical research on entrepreneurial activity and empirical support for the entrepreneurial startup process in developed countries, few studies have looked at Pakistan in this context. This paper uses data from the Global Entrepreneurship Monitor (GEM) for 2010-12 to establish relationships between total early-stage entrepreneurial activity (TEEA) and economic framework conditions (EFCs) as well as between cultural and individual factors and the birth ratio and conception ratio with regard to entrepreneurial activity.

Section 2 provides a brief introduction to the GEM data. Section 3 introduces the key concepts and empirical research in this field. Section 4 presents the data for analysis. The results are discussed in Section 5. Section 6 compares the TEEA rate and EFCs for 2010, 2011 and 2012 based on the GEM data. Section 7 concludes the paper with a set of recommendations.

\section{Global Entrepreneurship Monitor Data}

Over the past decade, there has been a marked shift from managerial to entrepreneurial capitalism. Various studies underscore the positive effects of entrepreneurship on economic growth. To support entrepreneurial capitalism, many countries have adapted their public policies to incorporate easier business formation, access to finance, protection of intellectual property rights and fair tax policies (Acs \& Szerb, 2007). However, according to the GEM data, there is a U-shaped relationship between entrepreneurship and the level of development. In addition, for high-income countries, entrepreneurship has a positive impact on growth, while the opposite is true for low-income countries (Sternberg and Wennekers, 2005).

Sternberg and Wennekers (2005) discuss the findings of the GEM conference and conclude that the impact of entrepreneurship differs along the stages of development. Despite the U-shaped relationship between entrepreneurship and economic development, low-income countries can still benefit from the prevalence of multinationals and

\footnotetext{
${ }^{1}$ See, for instance, Giacomin et al. (2011); Verheul et al. (2010); Block and Sandner (2009); Hechavarria and Reynolds (2009); McMullen, Bagby and Palich (2008); Hessels, van Gelderen and Thurik (2008); Morris et al. (2006).
} 
foreign direct investment through positive spillover effects, while highincome countries should opt for policies that encourage small business startups as high-growth startups and opportunity entrepreneurship lead to knowledge spillovers. However, in devising policies to encourage startup firms and businesses, policymakers should consider the regional framework conditions.

There are three stages of economic development: the factor-driven stage, the efficiency-driven stage and the innovation-driven stage. The GEM studies reveal that countries at the innovation-driven stage can enhance entrepreneurship by focusing on entrepreneurship education and training, while those at the factor-driven stage should work on moving to the efficiency-driven stage by focusing on their institutions and increasing entrepreneurial capacity (Acs, Desai \& Hessels, 2008).

Wong, Ho and Autio (2005) show that entrepreneurship is not just driven by new firms, but also by innovative and imitative entry of existing firms into new markets. This is based on the Schumpeterian principle of the 'entrepreneur as innovator'. Entrepreneurship on its own does not affect economic growth as much as the prevalence of fast-growing, innovative new firms. Higher levels of technological innovation lead to higher growth rates, but the GEM studies reveal that this is true only for a few countries. At the national level, innovation and new business creation can be treated as two separate phenomena.

\section{Literature Review}

The concept of nascent entrepreneurs has garnered increasing interest as researchers try to establish its relationship with education, age, entrepreneurial ability and economic conditions. According to Davidsson (2006), "nascent entrepreneurs" and "nascent ventures" are associated terms. There is also increasing focus on the relationship between entrepreneurship and the startup and gestation processes. Giacomin et al. (2011) show that the two types of entrepreneurs (necessity and opportunity entrepreneurs) differ in their progression from idea conception to business creation and growth.

The empirical literature on entrepreneurship focuses on the factors behind starting a new business, which influence entrepreneurial activity and economic development. Reynolds et al. (2000, 2001, 2002, 2004) state that these factors or EFCs drive TEEA, although other noneconomic conditions - government policy, education and experience, cultural and 
social factors and age - may also play a role. Business survival and growth is closely related to the gestation process. ${ }^{2}$ The motivation resulting from both positive and negative circumstances can lead to different gestation processes, which act as a catalyst for necessity and opportunity entrepreneurs (Bhola et al., 2006; Shapero \& Sokol, 1982). This stimulus comes from the underlying cultural and social characteristics.

There is strong evidence that deep-rooted cultural factors affect the conception of new businesses (Hayton, George \& Zahra, 2002; Inglehart \& Baker, 2000). Job dissatisfaction and the employment uncertainty related to political and social change are associated with higher self-employment (Noorderhaven et al., 2004). Materialism also acts as a catalyst for business startups. According to Uhlaner and Thurik (2007), societies with lower materialistic values tend to have lower levels of entrepreneurial activity.

Age and education are also key drivers of entrepreneurial activity. One strand of the literature states that, as individuals grow older, they are less likely to start a new business because they have become more riskaverse with age and prefer stability (Henley, 2007; Grilo \& Irigoyen, 2006). The other strand of the literature argues that older individuals have more professional experience, networks and accumulated financial capital, which encourages self-employment. Age may be associated with a better working knowledge of the industry and better business sense (Cowling \& Taylor, 2001; Coate \& Tennyson, 1992). An analysis of the GEM data also shows that self-reported confidence in one's ability to start and run a business leads to higher entrepreneurial activity (Arenius \& Minniti, 2005; Reynolds et al., 2001; Wagner, 2004).

Although GEM studies find that education has a positive impact on entrepreneurial activity, empirical studies suggest that education alone is not responsible for self-employment (Henley, 2007; Grilo \& Irigoyen, 2006; Davidsson \& Honig, 2003). Higher levels of education act as a safety net in case the new business venture fails. Better educated individuals are able to survive changing business environments and identify new trends faster (Davidsson \& Honig, 2003).

The relevance of age and education to entrepreneurial activity also holds for Pakistan. GEM reports on Pakistan cite entrepreneurial education as a significant EFC along with factors such as government programs and

2 See, for instance, Carter, Gartner and Reynolds (1996); Burke, Fraser and Greene (2010); Delmar and Shane (2003). 
policies, cultural and social norms, market openness, infrastructure, R\&D transfer, financial environment and internal market dynamics.

\section{Data and Methodology}

We use data from the GEM reports for Pakistan for 2010, 2011 and 2012, which also classifies other countries as factor-driven, efficiencydriven or innovation-driven economies. The TEEA rates have already been calculated for these three years. TEEA is defined as having "conducted specific activities to start a business in the past year," being "an owner or part owner (51 percent) of the business" and having "paid salaries for more than three months" (Frederick \& Monsen, 2011). The TEEA rate is used to establish the level of entrepreneurial activity. For this purpose, we further classify the TEEA rate as per Frederick and Monsen (2011): (3-42 months)

TEEA $=$ nascent entrepreneurs $(<3$ months $)+$ new entrepreneurs

To measure the level of economic development, we take the GDP per capita (GDPPC), adjusted for purchasing power parity (PPP) (in US\$), for all countries for 2010-12. Our model establishes a relationship between TEEA, GDPPC and GDPPC-squared as specified below:

$$
T E E A^{*}=\alpha_{0}+\alpha_{1} G D P P C+\alpha_{2} G D P P C^{2}+\varepsilon
$$

This estimation is used to establish the quadratic relationship between GDPPC and TEEA.

We determine the prevalence rate for all countries for 2012 by calculating the conception ratio and birth ratio. The conception ratio measures the number of individuals who have the required skills and perceive an entrepreneurial opportunity to start a business. This is done by taking the ratio of the prevalence rates for nascent entrepreneurship to potential entrepreneurship. Here, nascent entrepreneurs are defined as "individuals who are actively involved in setting up a business they will own or co-own; this business has not paid salaries, wages or any other payments to the owners for more than three months" (Qureshi \& Mian, 2012). Potential entrepreneurship is calculated as the weighted index of the response to two questions as reported in the GEM 2012 report for Pakistan: "there will be good startup opportunities where I live in the next six months" and "I have the knowledge, skill and experience required to start a new business." 
The birth ratio indicates how many individuals will succeed over time and comprises the prevalence rate of baby business owners and of nascent entrepreneurs. Baby business owners are defined as those individuals "who are currently an owner-manager of a new business... owning and managing a running business that has paid salaries, wages or any other payments to the owners for more than three months, but not more than 42 months" (Qureshi \& Mian, 2012). After calculating these ratios for each country in the 2012 GEM report, independent t-tests are executed for factor-driven, innovation-driven and efficiency-driven economies to compare the significance, scope and success of entrepreneurship across different economies. 1

\section{Results}

This section presents the regression results and ratio analysis.

\subsection{Regression Analysis}

Table 1 gives the regression results for specification (1). The sample comprises of all the countries that have been part of GEM studies since its inception (classified as: factor-driven, efficiency-driven and innovationdriven economies in GEM reports). The findings reveal that economic development measured by GDPPC (US\$) has an impact on TEEA. GDPPC starts rising the TEEA rate of an economy will start to fall, once it reaches its minimum it will start rising as GDPPC keeps on increasing. In the earlier phase of economic growth once the formation of business is done the business environment becomes less conducive for further entrepreneurship resulting in higher investment costs and lower returns for all. These low returns coupled with limited resources and small consumer base restrain the number of entrepreneurs from investing their time and effort in new venture. TEEA would fall. After the threshold level of GDPPC is reached, the TEEA rate begins to rise when the entrepreneurs find that the market has increased and the returns for investing in new business venture are far greater than the risk and opportunity cost involved. This finding is in accordance with Frederick and Monsen (2011), who also establish this Ushaped relationship between GDPPC and TEEA rate. 
Table 1: TEEA and GDPPC in GEM countries, 2010-12

\begin{tabular}{llll}
\hline & \multicolumn{1}{c}{$\mathbf{2 0 1 0}$} & \multicolumn{1}{c}{$\mathbf{2 0 1 1}$} & \multicolumn{1}{c}{$\mathbf{2 0 1 2}$} \\
\hline GDPPC & $-0.00125^{* * *}$ & $-0.000557^{* * *}$ & $-0.00107^{* * *}$ \\
& $(0.000191)$ & $(0.000154)$ & $(0.000163)$ \\
GDPPC-squared & $1.61 \mathrm{e}-08^{* * *}$ & $5.19 \mathrm{e}-09^{* *}$ & $1.22 \mathrm{e}-08^{* * *}$ \\
& $(3.31 \mathrm{e}-09)$ & $(2.17 \mathrm{e}-09)$ & $(2.52 \mathrm{e}-09)$ \\
Constant & $28.26^{* * *}$ & $20.90^{* * *}$ & $28.26^{* * *}$ \\
& $(2.315)$ & $(2.357)$ & $(2.178)$ \\
Observations & 46 & 43 & 64 \\
R-squared & 0.625 & 0.412 & 0.498 \\
\hline
\end{tabular}

Note: GDPPC is adjusted for PPP (US\$). Robust standard errors are given in parentheses and are significantly different from 0 at ${ }^{* * *} \mathrm{p}<0.01,{ }^{* *} \mathrm{p}<0.05$ and ${ }^{*} \mathrm{p}<0.1$.

Source: GEM Pakistan reports for 2010-12 and Trading Economics database.

Using specification (1), we obtain the predicted values for TEEA and establish a relationship between TEEA* and GDPPC for each year. This data (comprising of all countries included in GEM reports) also reveals a quadratic relationship between TEEA* and GDPPC (Figures 1 to 3).Pakistan has a low GDP but in comparison to other countries it has an even lower TEEA rate.

Figure 1: Fitted quadratic curve for TEEA and GDPPC, 2010

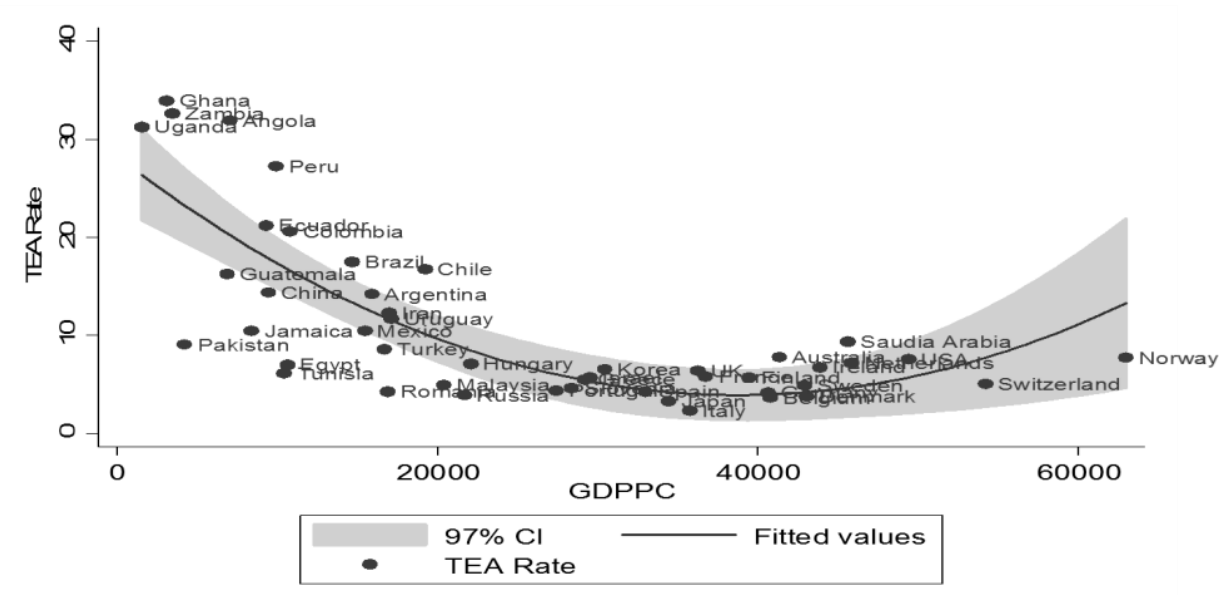

Note: GDPPC is adjusted for PPP (US\$). The sample comprises 46 GEM countries.

Source: GEM Pakistan report for 2010 and Trading Economics database. 
Figure 2: Fitted quadratic curve for TEEA and GDPPC, 2011

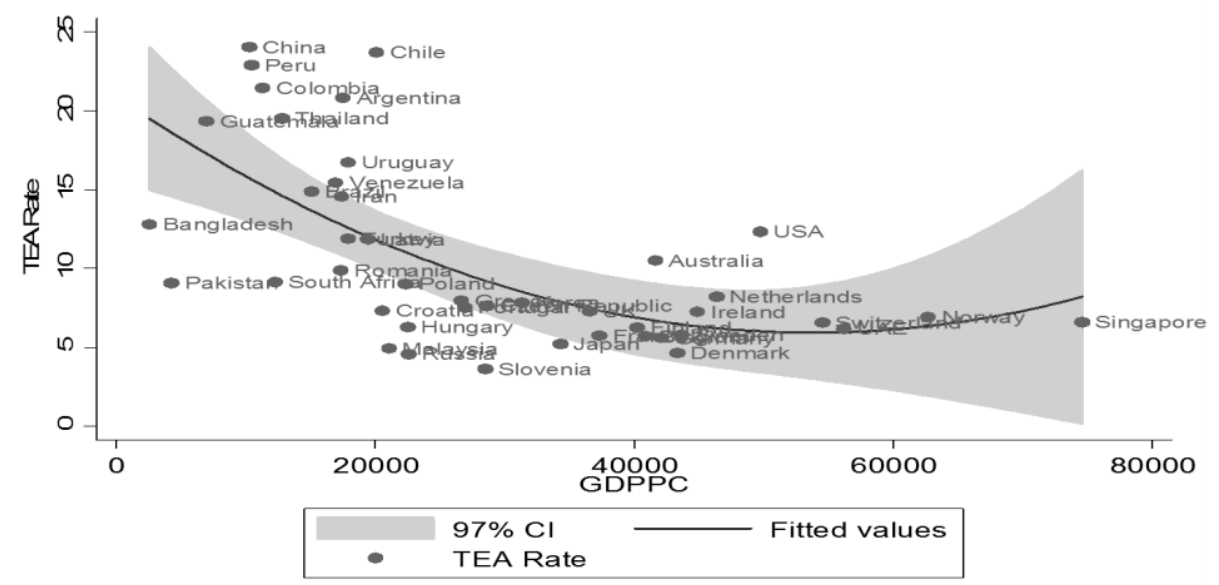

Note: GDPPC is adjusted for PPP (US\$). The sample comprises 43 GEM countries. Source: GEM Pakistan report for 2011 and Trading Economics database.

Figure 3: Fitted quadratic curve for TEEA and GDPPC, 2012

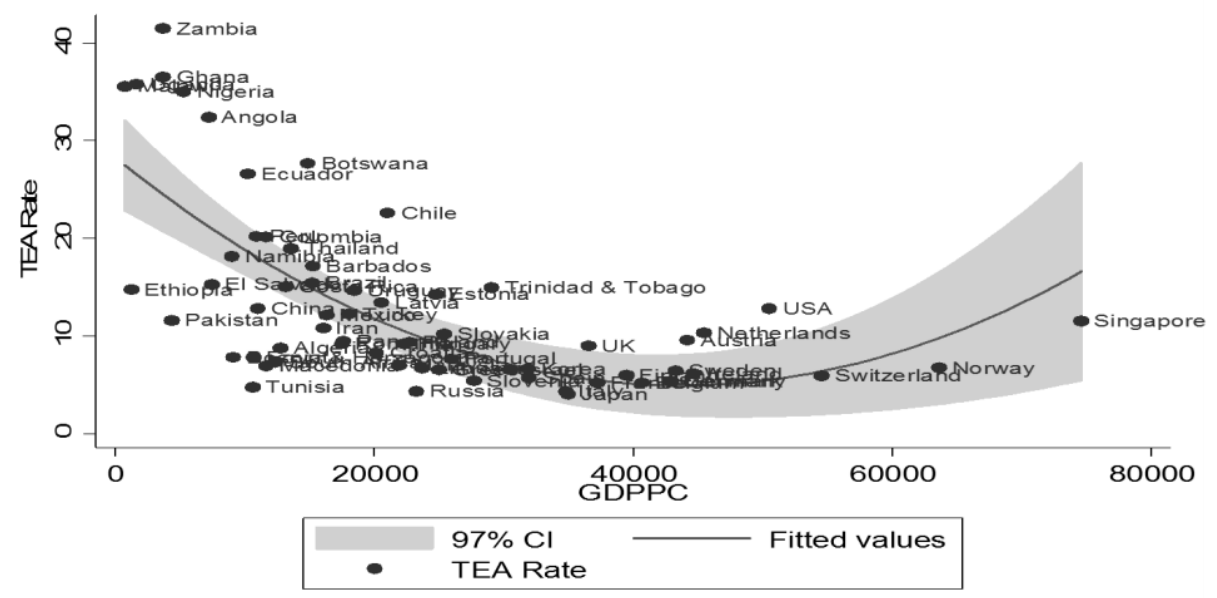

Note: GDPPC is adjusted for PPP (US\$). The sample comprises 64 GEM countries.

Source: GEM Pakistan report for 2012 and Trading Economics database.

Low GDPPC and TEEA* for Pakistan can be attributed to policy related EFCs as figures (5-7) taken from GEM reports 2012 indicate. Among the factor-driven, efficiency-driven and innovation-driven economies, Pakistan scores lower on government programs and policies. In comparison to innovation-driven economies, Pakistan also lags behind in entrepreneurial education. The literature links TEEA rate with government 
policies as they provide an incentive for an entrepreneur to establish a new business. If infrastructure and government policies are not conducive to new entrepreneurial activities, individuals may not invest their time and effort along with financial resources in a new business. This is also reflected in the analysis about Pakistan in GEM reports, a large portion of individuals do not find the environment conducive to starting a new business. Intuitively, factor driven economies TEEA* is low for lower levels of GDPPC, it implies that for Pakistan TEEA* in comparison to such economies is even lower.

\subsection{Ratio Analysis}

The country data is classified as factor-driven, efficiency-driven and innovation-driven economies as per the GEM reports. Tables 2 and 3 give the descriptive statistics for the conception ratio and the birth ratio respectively. The conception ratio shows how quickly new ideas are implemented while the birth ratio shows the sustainability of a business in a given sector once it is established. The literature (Arenius and Ehrstedt, 2008) indicates that birth ratio would be significant for factor-driven economies and conception ratio would be significant for innovation-driven economies. Efficiency-driven economies have an ambiguous relationship with birth and conception ratios. By GEM classification, efficiency-driven economies include those that have moderate EFCs implying that such countries have the ability to start a new business by innovation (conception ratio) and are also persistent in using the same business technology (birth ratio). We conducted t-tests in order to see the significance of the two respective ratios according to the economic classification done in GEM report 2012 (factor-driven, efficiency-driven and innovation-driven economies). These independent $t$-test results reveal that the success of the entrepreneurial startup process varies across economies.

Table 2 gives the descriptive statistics for the conception ratio of the three types of economies where the conception ratio indicates the rate at which new ideas are conceived and implemented. The t-test results showed that the only significant difference lies between the conception ratio of innovation-driven and efficiency-driven economies. 
Table 2: Descriptive statistics for conception ratio: GEM countries, 2012

$\begin{array}{lccccc}\text { Country grouping } & \mathbf{N} & \text { Mean } & \text { SD } & \text { T } & \text { Significance } \\ \text { Innovation-driven economies } & 24 & 0.127 & 0.061 & 2.2523 & 0.000^{* *} \\ \text { Efficiency-driven economies } & 30 & 0.163 & 0.054 & -0.1320 & \text { Not significant } \\ \text { Factor-driven economies } & 13 & 0.166 & 0.091 & 1.5247 & \text { Not significant }\end{array}$

Note: The t-statistics are calculated at a 95 percent confidence interval and are significantly different from 0 at ${ }^{* * *} \mathrm{p}<0.01,{ }^{* *} \mathrm{p}<0.05$ and ${ }^{*} \mathrm{p}<0.1$.

Source: Authors' calculations based on GEM data for 2012.

Table 3 gives the descriptive statistics for the birth ratio which measures the steadfastness of entrepreneurs in continuing to run their business such that they can earn profits for longer periods. Our t-test results for birth ratio reveal factor-driven economies to be significantly different from innovation-driven economies. This shows that factor-driven economies are less likely to innovate.

Table 3: Descriptive statistics for birth ratio: GEM countries, 2012

\begin{tabular}{lccccc}
\hline Country grouping & $\mathbf{N}$ & Mean & SD & T & Significance \\
\hline Innovation-driven economies & 24 & 0.785 & 0.310 & 0.1722 & Not significant \\
Efficiency-driven economies & 30 & 0.803 & 0.437 & -2.7143 & $0.000^{* * *}$ \\
Factor-driven economies & 13 & 1.444 & 1.125 & 2.7143 & $0.000^{* *}$ \\
\hline
\end{tabular}

Note: The t-statistics are calculated at a 95 percent confidence interval and are significantly different from 0 at ${ }^{* * *} \mathrm{p}<0.01,{ }^{* *} \mathrm{p}<0.05$ and ${ }^{*} \mathrm{p}<0.1$.

Source: Authors' calculations based on GEM data for 2012.

As a factor-driven economy for which the birth ratio is significant in comparison with innovation driven economies, Pakistan may not be developing new technology but it does have a significant number of large established businesses. This is supported by the regression analysis, which shows that Pakistan has a lower TEEA* rate than other countries, where the TEEA rate measures new business ventures.

\section{TEEA in Pakistan at a Glance, 2010-12}

Figure 4 (taken from GEM report, (Quershi and Mian, 2012)) shows the TEEA rate for the four provinces of Pakistan over 2010-12. In Sindh, the TEEA rate increases in 2011 from 2010 and then falls in 2012. In Punjab, the TEEA rate falls slightly in 2011 and then rises in 2012. The most prominent changes can be seen in KP and Balochistan. In Balochistan, the TEEA rate falls over all three years while in $\mathrm{KP}$, it increases, with a very high margin 
in 2012. The fall in Balochistan can be attributed to its poor infrastructure and political instability, while the rise in KP may have stemmed from its better financial environment.

Figure 4: TEEA rates in Pakistan, 2010-12

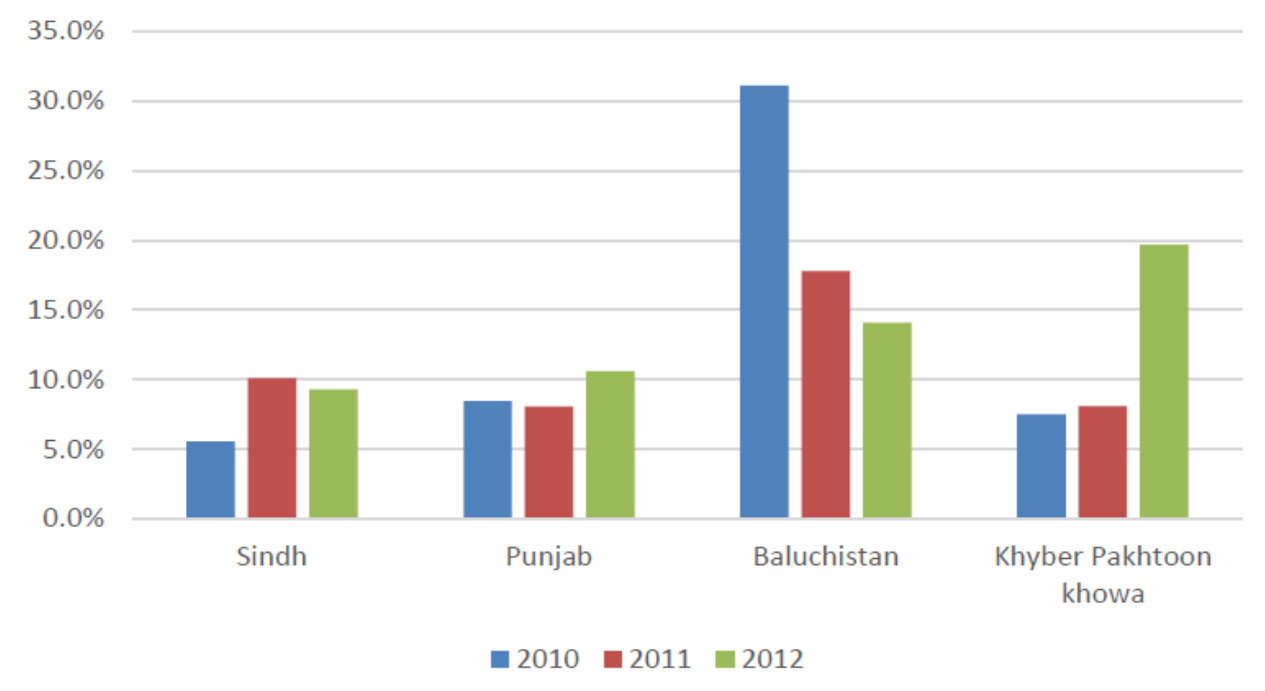

Source: GEM Pakistan reports for 2010-12.

The following Figures $5-7$ are also taken from GEM reports for the year 2012 (Qureshi and Mian, 2012). On the basis of the scores generated in this report we compare the economic framework conditions (EFCs) of Pakistan to a group of other economies that are either innovation-driven, efficiency driven, or factor-driven to evaluate where Pakistan stands amongst such countries.

Figure 5 compares Pakistan with the sample of innovation-driven economies on the basis of policy and environment factors. With regard to government programs, Pakistan has the lowest average while Germany has the highest. This means that government programs in Germany are designed to facilitate new business startups. On government policy (bureaucratic red tape and priority), Pakistan has the lowest rating while Singapore has the highest, followed by South Korea. On financial environment, Pakistan ranks third while Singapore scores the highest. Looking at the data, we can say that, in comparison to innovation-driven countries, Pakistan ranks low in terms of starting a new business. 
Figure 5: Mean EFC scores for Pakistan relative to innovation-driven economies (policy and environment factors)

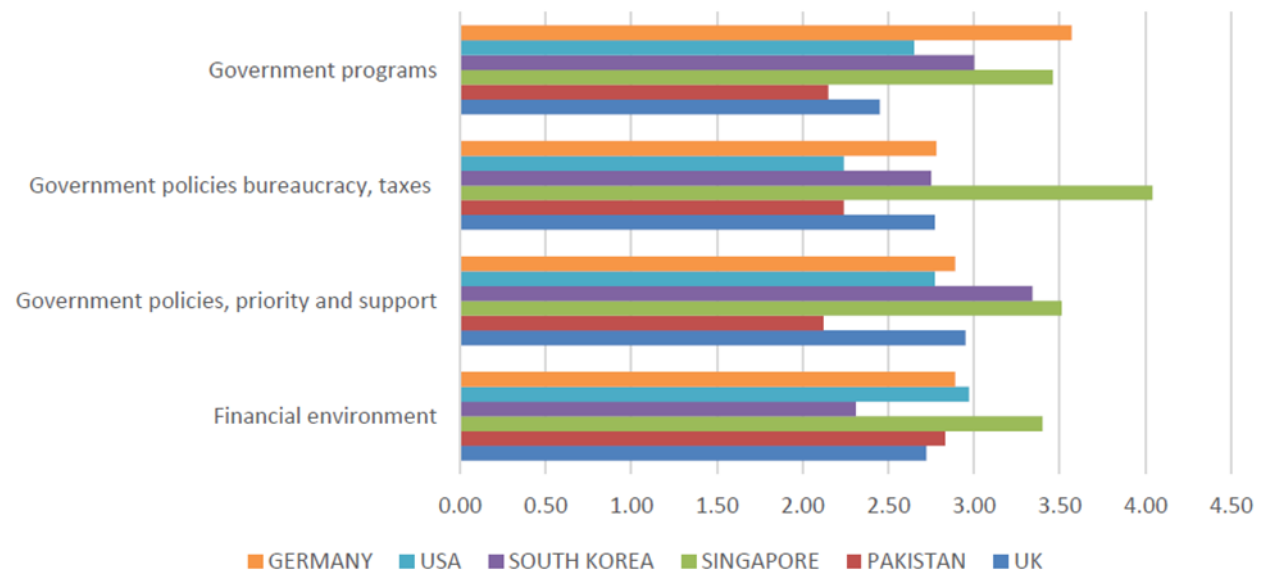

Source: GEM Pakistan report for 2012.

Figure 6 compares Pakistan's government policies and programs and its financial conditions with efficiency-driven economies. Of the seven countries under consideration, Pakistan ranks sixth on government programs, fifth on bureaucratic red tape and seventh on government priority and support. In the latter case, even Mexico and South Africa have a better mean average. In the financial environment category, Pakistan is second with mean average above that of China and Thailand.

Figure 6: Mean EFC scores for Pakistan relative to efficiency-driven economies (policy and environment factors)

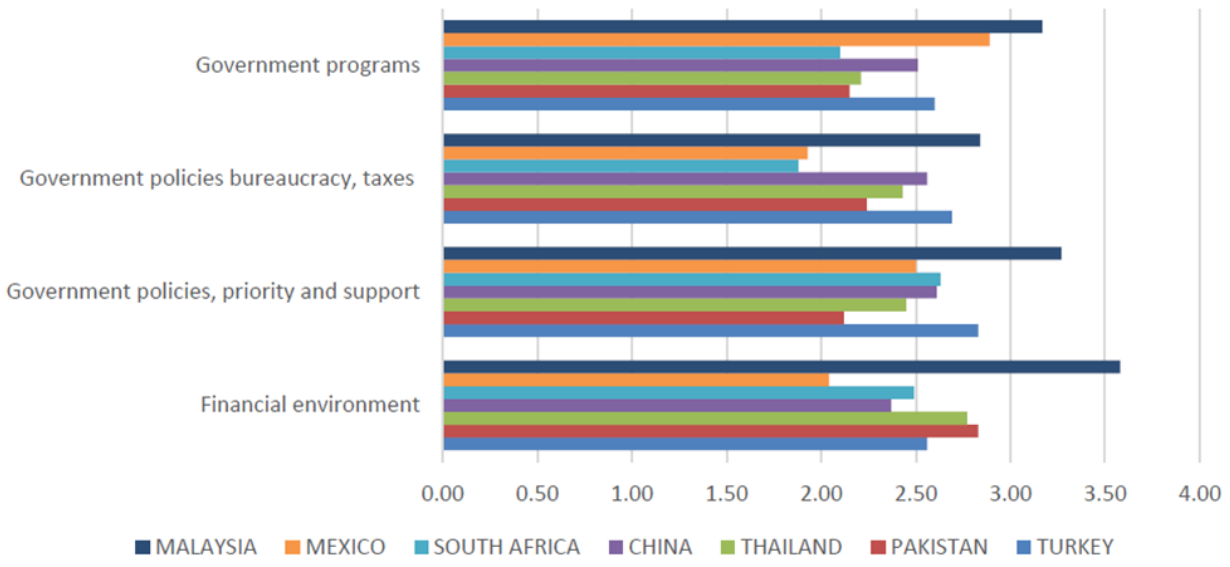

Source: GEM Pakistan report for 2012. 


\section{Figure 7: Mean EFC scores for Pakistan relative to factor-driven economies (policy and environment factors)}

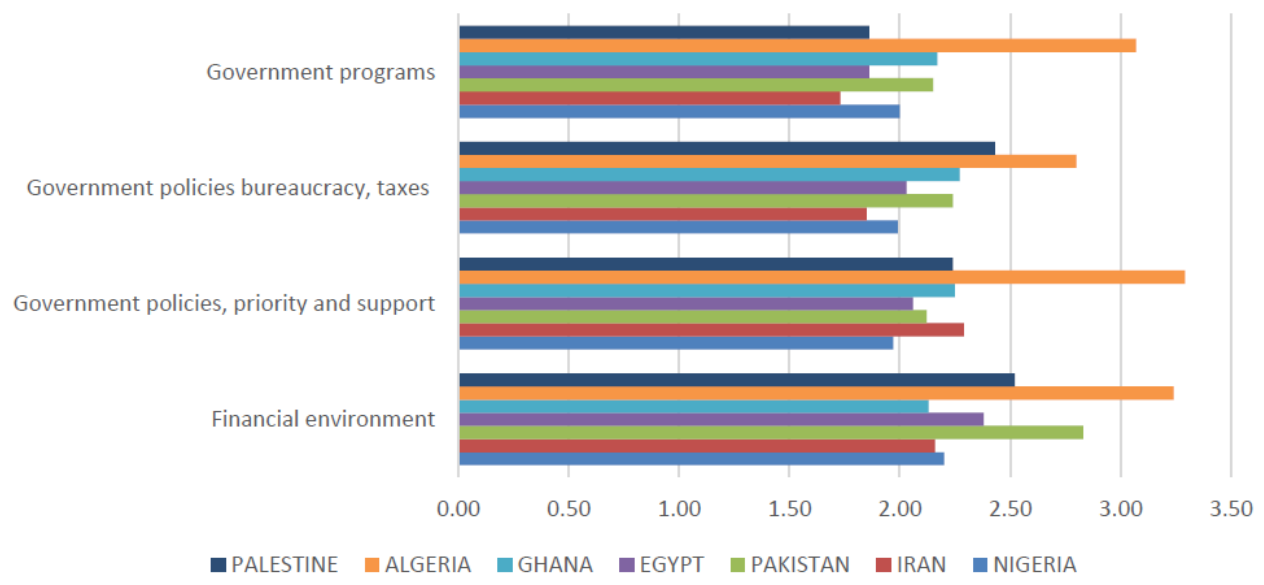

Source: GEM Pakistan report for 2012.

Figure 7 compares Pakistan with other factor-driven economies (Palestine, Iran Nigeria, Egypt and Ghana). In comparison to these countries, Pakistan ranks third on government programs, fourth on bureaucracy and taxes and fifth on policy support and priority. The financial environment in Pakistan is the second most conducive after Algeria.

Overall, relative to these factor-driven, efficiency-driven and innovation-driven economies, Pakistan ranks low in government programs and policies that facilitate entrepreneurship which could be the reason for its deviation from the quadratic trend curve for GDPPC and TEEA* (Figures 1-3). Despite having a financial environment that is conducive to entrepreneurship, the country's GDPPC (US\$) remains low. To improve its TEEA, Pakistan should adopt more favorable government programs and policies that facilitate investment and attract nascent entrepreneurs.

\section{Conclusion}

This paper examines GEM data in terms of economic development (measured by GDPPC) and TEEA, which tend to have a significant relationship with each other. Their quadratic relationship shows that at higher levels of GDPPC, TEEA rises. Pakistan is an outlier and lies below the trend curve, due to its low TEEA rate which shows that the government needs to introduce better policies and programs to foster entrepreneurship. 
The ratio analysis shows that, for conception ratio, innovationdriven economies are significantly different from efficiency-driven economies owing to their quick adoption of new technology and ideas while for birth ratio, factor-driven economies are significantly different from innovation-driven economies. Since Pakistan is a factor-driven economy so this means that persistence of businesses here could generate higher growth over time. But to sustain businesses the government needs to provide the right set of policies that facilitate entrepreneurs and attract new investors. If such a mechanism is in place then Pakistan's TEEA rate could rise with its GDPPC. 


\section{References}

Acs, Z. J., Desai, S., \& Hessels, J. (2008). Entrepreneurship, economic development and institutions. Small Business Economics, 31(3), 219234.

Acs, Z. J., \& Szerb, L. (2007). Entrepreneurship, economic growth and public policy. Small Business Economics, 28(2/3), 109-122.

Aldrich, H. E., \& Martínez, M. A. (2001). Many are called, but few are chosen: An evolutionary perspective for the study of entrepreneurship. Entrepreneurship Theory and Practice, 25(4), 41-56.

Arenius, P., \& Minniti, M. (2005). Perceptual variables and nascent entrepreneurship. Small Business Economics, 24(3), 233-247.

Arenius, P., \& Ehrstedt, S. (2008). Variation in the level of activity across the stages of the entrepreneurial startup process-evidence from 35 countries. Estudios de Economia, 35(2), 133-152.

Bhola, R., Verheul, I., Thurik, R., \& Grilo, I. (2006). Explaining engagement levels of opportunity and necessity entrepreneurs (Report No. H200610). Zoetermeer: EIM Business and Policy Research.

Block, J., \& Sandner, P. (2009). Necessity and opportunity entrepreneurs and their duration in self-employment: Evidence from German microdata. Journal of Industry, Competition and Trade, 9(2), 117-137.

Burke, A., Fraser, S., \& Greene, F. J. (2010). The multiple effects of business planning on new venture performance. Journal of Management Studies, 47(3), 391-415.

Carter, N. M., Gartner, W. B., \& Reynolds, P. D. (1996). Exploring start-up event sequences. Journal of Business Venturing, 11(3), 151-166.

Coate, S., \& Tennyson, S. (1992). Labor market discrimination, imperfect information and self-employment. Oxford Economic Papers, 44(2), 272-288.

Cowling, M., \& Taylor, M. (2001). Entrepreneurial women and men: Two different species? Small Business Economics, 16(3), 167-175. 
Davidsson, P. (2006). Nascent entrepreneurship: Empirical studies and developments (Foundations and Trends in Entrepreneurship). Hanover, MA: Now Publishers.

Davidsson, P., \& Honig, B. (2003). The role of social and human capital among nascent entrepreneurs. Journal of Business Venturing, 18(3), 301-331.

Delmar, F., \& Shane, S. (2003). Does business planning facilitate the development of new ventures? Strategic Management Journal, 24(12), 1165-1185.

Frederick, H., \& Monsen, E. (2011). New Zealand's perfect storm of entrepreneurship and economic development. Small Business Economics, 37(2), 187-204.

Giacomin, O., Janssen, F., Guyot, J. L., \& Lohest, O. (2011). Firm gestation process: Is there a difference between necessity and opportunity entrepreneurs? Frontiers of Entrepreneurship Research, 31(4), art. 7.

Grilo, I., \& Irigoyen, J.-M. (2006). Entrepreneurship in the EU: To wish and not to be. Small Business Economics, 26(4), 305-318.

Hayton, J. C., George, G., \& Zahra, S. A. (2002). National culture and entrepreneurship: A review of behavioral research. Entrepreneurship Theory and Practice, 26(4), 33-52.

Hechavarria, D. M., \& Reynolds, P. (2009). Cultural norms and business startups: The impact of national values on opportunity and necessity entrepreneurs. International Entrepreneurship and Management Journal, 5(4), 417-437.

Henley, A. (2007). Entrepreneurial aspiration and transition into selfemployment: Evidence from British longitudinal data. Entrepreneurship and Regional Development, 19(3), 253-280.

Hessels, J., van Gelderen, M., \& Thurik, R. (2008). Entrepreneurial aspirations, motivations and their drivers. Small Business Economics, 31(3), 323-339.

Inglehart, R., \& Baker, W. E. (2000). Modernization, cultural change and the persistence of traditional values. American Sociological Review, $65,19-51$. 
McMullen, J. S., Bagby, D. R., \& Palich, L. E. (2008). Economic freedom and the motivation to engage in entrepreneurial action. Entrepreneurship Theory and Practice, 32(5), 875-896.

Mian, S. A., \& Qureshi, M. S. (2010). Global Entrepreneurship Monitor Pakistan report 2010. Karachi: Institute of Business Administration.

Mian, S. A., \& Qureshi, M. S. (2011). Global Entrepreneurship Monitor Pakistan report 2011. Karachi: Institute of Business Administration.

Morris, M. H., Miyasaki, N. N., Watters, C. E., \& Coombes, S. M. (2006). The dilemma of growth: Understanding venture size choices of women entrepreneurs. Journal of Small Business Management, 44(2), 221-244.

Noorderhaven, N., Thurik, R., Wennekers, S., \& van Stel, A. (2004). The role of dissatisfaction and per capita income in explaining selfemployment across 15 European countries. Entrepreneurship Theory and Practice, 28(5), 447-466.

Qureshi, M. S., \& Mian, S. A. (2012). Global Entrepreneurship Monitor Pakistan report 2012. Karachi: Institute of Business Administration.

Reynolds, P. D., Bygrave, W. D., \& Autio, E. (2004). Global Entrepreneurship Monitor 2003 executive report. Kansas, MO: Kauffman Foundation.

Reynolds, P. D., Bygrave, W. D., Autio, E., ... Hay, M. (2002). Global Entrepreneurship Monitor 2002 executive report. Kansas, MO: Kauffman Foundation.

Reynolds, P. D., Camp, S. M., Bygrave, W. D., ... Hay, M. (2001). Global Entrepreneurship Monitor 2001 executive report. Kansas, MO: Kauffman Foundation.

Reynolds, P. D., Hay, M., Bygrave, W. D., ... Autio, E. (2000). Global Entrepreneurship Monitor 2000 executive report. Kansas, MO: Kauffman Foundation.

Shapero, A., \& Sokol, L. (1982). The social dimensions of entrepreneurship. In C. Kent, D. Sexton \& K. Vesper (Eds.), Encyclopedia of entrepreneurship (pp. 72-90). Englewood Cliffs, NJ: Prentice-Hall. 
Sternberg, R., \& Wennekers, S. (2005). Determinants and effects of new business creation using Global Entrepreneurship Monitor data. Small Business Economics, 24(3), 193-203.

Uhlaner, L., \& Thurik, R. (2007). Post-materialism influencing total entrepreneurial activity across nations. Journal of Evolutionary Economics, 17(2), 161-185.

Verheul, I., Thurik, R., Hessels, J., \& van der Zwan, P. (2010). Factors influencing the entrepreneurial engagement of opportunity and necessity entrepreneurs (Report No. H201011). Zoetermeer: EIM Business and Policy Research.

Wagner, J. (2004). Nascent entrepreneurs (Discussion Paper No. 1293). Bonn: Institute for the Study of Labor.

Wong, P. K., Ho, Y. P., \& Autio, E. (2005). Entrepreneurship, innovation and economic growth: Evidence from GEM data. Small Business Economics, 24(3), 335-350.

World Bank. (2016). Doing business 2016: Measuring regulatory quality and efficiency. Washington, DC: Author. 